\title{
Applying Service System Framework to Not-for-Profit Sector: A Case of Akhuwat Foundation
}

\author{
Ghazala Yasmeen', Yasir Rashid ${ }^{2}$, Yunkai Zhai ${ }^{1,3}{ }^{*}$, Abdul Rashid Kausar ${ }^{2}$, Asif Jabbar ${ }^{4}$, \\ Yacong Gao1, Caihong Bu${ }^{1}$, Liuyan Guo ${ }^{1}$
}

${ }^{1}$ School of Management Engineering, Zhengzhou University, Zhengzhou, China

${ }^{2}$ School of Business and Economics, University of Management \& Technology, Lahore, Pakistan

${ }^{3}$ National Engineering Laboratory for Internet Medical Systems and Applications, Zhengzhou, China

${ }^{4}$ School of Management, Hefei University of Technology, Hefei, China

Email: *zhaiyunkai@zzu.edu.cn

How to cite this paper: Yasmeen, G., Rashid, Y., Zhai, Y., Kausar, A. R., Jabbar, A., Gao, Y. C., Bu, C. H., \& Guo, L. Y. (2020). Applying Service System Framework to Not-for-Profit Sector: A Case of Akhuwat Foundation. Open Journal of Business and Management, 8, 2162-2177.

https://doi.org/10.4236/ojbm.2020.85132

Received: July 19, 2020

Accepted: September 5, 2020

Published: September 8, 2020

Copyright ( 2020 by author(s) and Scientific Research Publishing Inc. This work is licensed under the Creative Commons Attribution International License (CC BY 4.0).

http://creativecommons.org/licenses/by/4.0/ (c) (i) Open Access

\begin{abstract}
Service is now considered as the basis of exchange and defined as "the use and application of competencies and knowledge for mutual benefits". In the current stream of development, service systems emerge as widely accepted, interesting and logical area to study the concepts related to service interactions. Service systems are dynamic entities which interact with each other and integrate their resources to co-create value. This paper characterizes Akhuwat Foundation Microfinance project as a Service System with the application of service system framework developed by Lyon and Tracy. The purpose of the study is to evaluate Akhuwat microfinance project to understand its service activities and to define business exchanges from the perspective of reciprocal benefits. Assuming the interprevitist assumptions, a qualitative approach was adopted and data was gathered through in-depth interviews with the employees of Akhuwat microfinance project. Data analysis revealed that Akhuwat microfinance is in fact, a true representation of a service system. Their objectives, processes, control and performances are service oriented. The main focus of transactions with donors, borrowers and other network partners is poverty alleviation, financial empowerment and a sustainable society. This paper motivates future researchers to apply the service system framework in other sectors, and characterize organizations that are, in its true essence service oriented.
\end{abstract}

\section{Keywords}

Service Dominant Logic, Service Science, Value Co-Creation, Service System Framework, Akhuwat Foundation 


\section{Introduction}

The concept of "service" was first introduced in service dominant logic (S-D logic) by Vargo \& Luschin 2004 in the field of marketing. Since then, the traditional view of "goods \& services" (where goods were treated as tangible/operand and services as intangible/operant products) is shifted towards "service" (application of operant resources). According to SD logic view, all economies are engaged in service as they apply and integrate their operant resources (competences, skills and knowledge) to get or to provide benefits and they exchange their competences rather than goods. Goods play the role of delivery vehicle for the transportation of service (Vargo et al. 2010b; Vargo \& Lusch, 2018; Vargo et al. 2020). All economic activities are done for the reciprocal exchange of service. With the emergence of this new perspective, there is a need to view the existing organizations and their operations with the lens of SD logic and service systems perspective.

Service science is considered as a part of systems science which deals with the artificial and human made world (Simon, 1996). Service science is concerned with the study of service systems which is defined as a value co-creation configuration (Maglio \& Spohrer, 2008, Maglio, et al., 2019). The entities which interact with other entities and integrate their tangible and intangible resources for value co-creating and mutual benefits are called service system (Maglio et al., 2009, Maglio, et al., 2019). This value co-creation configuration is consisted of the resources of people, technology, organization and shared information.

According to service dominant logic, all economies are service economies and service science views all entities or organizations as service systems which interact with other service systems, so organizations can be evaluated with service perspective. This paper aims to view the Akhuwat Microfinance initiative as a service system with the perspective of SD logic and service science. A well-known and widely applied service system framework developed by Lyons \& Tracy (2013) is used to depict the service system of Akhuwat microfinance project.

\section{Literature Research/Theoretical Basis}

\subsection{Service Dominant Logic}

Vargo \& Lusch (2004) introduced the alternative perspective of exchange which focuses on service rather than goods. According to SD logic, service can be defined as a value co-creating process by applying operant resources (competences and skills-dynamic and intangible resources, capable to create value) which act on operand resources (goods or object-tangible and static which need some actions to make it valuable) for the benefits of all actors involved in an interactive relationship. Service is now considered as the basis of economic exchange, leading to meaningful interactions and are ciprocal exchange of service (Vargu \& Lusch 2004; Vargo et al. 2020). 
Vargo \& Lusch (2004) gave more importance to operant resources rather than operand resources. Traditional view of exchange focuses on physical goods and tangible items and considered them as basic unit of exchange but S-D view emphasized that behind the production of any product or goods, it is the operant resources (competences, knowledge and skills) which are used or applies on operand resources (raw material, machinery and other physical items) that make them valuable.

The theoretical foundation of service view is based on 11 fundamental premises (FP's) and five axioms of S-D logic (Vargo 2011; Winklhofer, Palmer, \& Brodie 2007). In their first paper Vargo \& Lusch (2004) introduced 8 foundational premises (FPs) and further with modification and extension, 10 FP's and 4 axioms were established. Lusch and Vargo (2014); Vargo et al. (2020) condensed 10 FPs into 4 FPs as axioms (FP1, FP6, FP9 and FP10) from which other FPs can be described. Lusch and Vargo (2016) enhanced these axioms with the addition of FP11 (Williams \& Aitken, 2011) and now 11 FP's and 5 axioms are established. These FP's and axioms are pre-theoretical building blocks to develop an emerging theoretical paradigm of S-D logic (Brodie, Saren, \& Pels 2011). 11 Fp's and five axioms are described in detail in Table 1.

\subsection{Service Science}

Service science is short term of Service Science Management Engineering and Design (SSMED) which is also called an integrative science. Service science explains the investment of internal, and external resources in the process of exploration and exploitation to achieve higher value creation and opportunity share (March 1991). According to research perspective, service science is a part of systems science which deals only with artificial world or human made world (Simon (1996).

Service science is an evolving interdisciplinary field which combines human and institutional understanding along with technology and business to label and describe the different types of service systems. These systems develop interactions with each other and integrate resources to co-create value mutually (Maglio \& Spohrer 2008; Maglio, et al., 2019). Systems or service systems can be defined as value co-creating configurations consisting of four different types of resources which are people, technology, shared information and value propositions connecting internal and external service systems (Maglio \& Spohrer 2008, Maglio et al., 2019). The concept of service as defined by Vargo \& Lusch (2014) was considered as a theoretical ground for the expansion of service science and further to study service systems (Lusch, Vargo, \& Wessels 2008, Maglio \& Spohrer 2008). Service systementity can be an individual (at small level) or an organization or economy (at large level) that interacts with other individuals, organizations and global economies for mutual benefited value co-creation (Maglio \& Spohrer, 2008, Maglio et al., 2019). 
Table 1. Service-dominant logic foundational premise.

\begin{tabular}{|c|c|c|c|}
\hline FPs & $\begin{array}{l}\text { Original Foundational Premise } \\
\qquad(2004)\end{array}$ & $\begin{array}{l}\text { Modified Foundational Premise } \\
\qquad(2008)\end{array}$ & $\begin{array}{l}\text { Updated Foundational Premise } \\
\qquad(2016)\end{array}$ \\
\hline FP1 & $\begin{array}{l}\text { The application of specialized skill(s) } \\
\text { and knowledge is the fundamental } \\
\text { unit of exchange }\end{array}$ & $\begin{array}{l}\text { Service is the fundamental } \\
\text { basis of exchange }\end{array}$ & $\begin{array}{l}\text { Service is the fundamental basis of exchange } \\
\text { AXIOM STATUS }\end{array}$ \\
\hline FP2 & $\begin{array}{l}\text { Indirect exchange masks the } \\
\text { fundamental unit of exchange }\end{array}$ & $\begin{array}{l}\text { Indirect exchange masks the } \\
\text { fundamental basis of exchange }\end{array}$ & $\begin{array}{l}\text { Indirect exchange masks the fundamental } \\
\text { basis of exchange }\end{array}$ \\
\hline FP3 & $\begin{array}{l}\text { Goods are a distribution } \\
\text { mechanism for service provision }\end{array}$ & $\begin{array}{l}\text { Goods are a distribution mechanism } \\
\text { for service provision }\end{array}$ & $\begin{array}{l}\text { Goods are a distribution mechanism } \\
\text { for service provision }\end{array}$ \\
\hline FP4 & $\begin{array}{l}\text { Knowledge is the fundamental } \\
\text { source of competitive advantage }\end{array}$ & $\begin{array}{l}\text { Operant resources are the fundamental } \\
\text { source of competitive advantage }\end{array}$ & $\begin{array}{l}\text { Operant resources are the fundamental } \\
\text { source of strategic benefit. }\end{array}$ \\
\hline FP5 & All economies are services economies & All economies are service economies & All economies are service economies \\
\hline FP6 & The customer is always a co-producer & $\begin{array}{l}\text { The customer is always } \\
\text { a co-creator of value }\end{array}$ & $\begin{array}{l}\text { Value is cocreated by multiple actors, } \\
\text { always including the beneficiary. } \\
\text { AXIOM STATUS }\end{array}$ \\
\hline FP7 & $\begin{array}{l}\text { The enterprise can only make value } \\
\text { propositions }\end{array}$ & $\begin{array}{l}\text { The enterprise cannot deliver value, } \\
\text { but only offer value propositions }\end{array}$ & $\begin{array}{l}\text { Actors cannot deliver value but can } \\
\text { participate in the creation and } \\
\text { offering of value propositions. }\end{array}$ \\
\hline FP8 & $\begin{array}{l}\text { A service-centered view is } \\
\text { customer oriented and relational }\end{array}$ & $\begin{array}{l}\text { A service-centered view is inherently } \\
\text { customer oriented and relational }\end{array}$ & $\begin{array}{l}\text { A service-centered view is inherently } \\
\text { beneficiary oriented and relational. }\end{array}$ \\
\hline FP9 & $\begin{array}{l}\text { Organizations exist to integrate and } \\
\text { transform micro specialized } \\
\text { competences into complex services that } \\
\text { are demanded in the marketplace }\end{array}$ & $\begin{array}{l}\text { All social and economic actors } \\
\text { are resource integrators }\end{array}$ & $\begin{array}{l}\text { All social and economic actors } \\
\text { are resource integrators } \\
\text { AXIOM STATUS }\end{array}$ \\
\hline FP10 & & $\begin{array}{l}\text { Value is always uniquely and } \\
\text { phenomenologically determined } \\
\text { by the beneficiary }\end{array}$ & $\begin{array}{l}\text { Value is always uniquely and } \\
\text { phenomenologically determined } \\
\text { by the beneficiary } \\
\text { AXIOM STATUS }\end{array}$ \\
\hline FP11 & & & $\begin{array}{l}\text { Value co-creation is coordinated through } \\
\text { actor-generated institutions and } \\
\text { institutional arrangements. } \\
\text { AXIOM STATUS }\end{array}$ \\
\hline
\end{tabular}

Source: Vargo \& Lusch, (2016).

Good dominant logic (GD logic) and service dominant logic have different perspectives to establish theoretical framework for service science and service systems. The traditional view (G-D logic) expresses economic exchange influenced by monetary incentives for creating value with the passive or silent role of customer and production occurs in isolated environment away from customers. GD perspective primarily focuses on manufacturing and distribution/supply of physical goods or tangible products and studies services as intangible product with specific attributes (Vargo et al. 2010b). S-D logic assigns the service as central position in the procedure of co-creating value and allocates goods as a 
role of service delivery vehicle for service provision.

S-D logic provides the theoretical bases for the emergence of service science and service system (Maglio \& Spohrer, 2008). S-D logic argues that service is foundation or basis for all economic activities and exchanges and all economies which are engaged in exchange of service can be considered as service economies. Literature concerned with the growth of service science, recommends that significance of the discipline of service science nourished with the evolution of service economy (Spohrer et al. 2007). With the development of service science, consideration of intangible and dynamic aspects of resources and their exchange has drawn.

\subsection{Service System}

Service systems are entities which interact with each other and integrate their operand and operant resource in the process of value co-creating activities and make reciprocal exchange of service for mutual benefits (Maglio et al., 2009). Service system is defined as dynamic value-co-creating configurations of resources and these resources are connected through value proposition (Maglio \& Spohrer, 2008, Maglio et al., 2019). Service systems are basic unit of analysis with the capability to improve the status of other systems by resource sharing and also are capable to enhance self-status by external resource's acquiring (Spohrer et al., 2008). Service systems are engaged in three activities that are 1) value proposing, 2) proposal accepting and 3) value realizing (Spohrer et al., 2008).

Service system performs the role of provider as well as receiver that are connected through value proposition in a value creating network system (Normann 2001). While functioning normatively, service systems connect the resources of people, information and technology by proposing value with the objective of co-creating value for systems within and across the other systems involved in reciprocal exchange of resources. Core function of service system is to transfer and share resources within and among other Systems (Maglio, Bailey, \& Gruhl, 2007).

\subsection{Service System Framework}

According to FP5 of S-D logic, all economies are considered as service economies. With this view, it is a need to revisit the current and existing organizations as service systems to develop a mechanism of applying service and to co-create value. Spohrer \& Maglio (2010) proposed ten fundamental concepts to understand the concept of value co-creation. These 10 fundamental principles: resources, access rights, entities, value co-creation interactions, governance interactions, outcomes, measures, stakeholders, networks and ecology, can be applied to recognize and characterize service system (Lyons \& Tracy (2013).

Lyons \& Tracy (2013) developed service system framework (as depicted in Figure 1) on the basis of 10 fundamental concepts presented by Spohrer \& Kwan (2009). This framework is explained in detail below. 


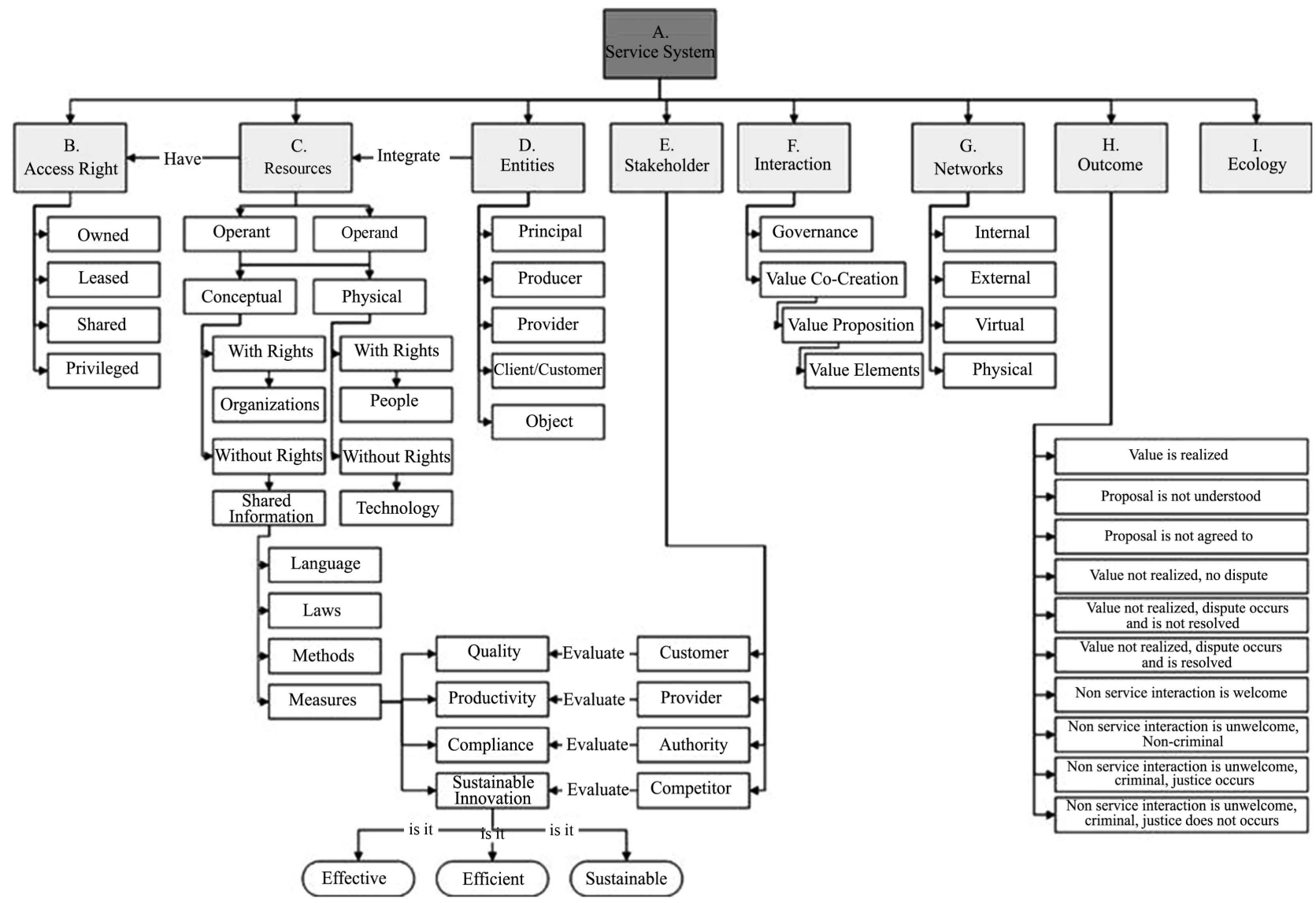

Figure 1. Service system framework. Source: Lyons \& Tracy (2013).

\subsubsection{Resources}

Service system entities integrate their resources for the creation of mutually beneficial value and exchange service reciprocally. Simply resources can be categorized into two major types: operant and operand resources. Operand resources are visible, tangible, physical resources like physical goods on which operant resources acts. Operant resources are non-physical, invisible and intangible resources like competences, skills and knowledge which produce effects. According to the above definition of service system, four types of resources integrate with each other to co-create value that are people, organization, and technology and shared information (Maglio \& Spohrer, 2008; Bryson, Daniels, \& Warf, 2004).

Broadly resources can be classified into four categories (as shown in Figure 1): physical with rights (people), non-physical with rights (organizations, businesses, nations), non-physical with no rights (shared information, and physical with no rights (technology, environment) (Spohrer \& Maglio (2010). Spohrer et al. (2007) discussed the shared information and described its three types: language, law and measures. Language provides mean or medium to transfer information through words, codes and vocabulary. Rights originate from laws and laws are legitimacy to ensure the compliance issues of regulations and policies while measures are used to evaluate the performance. 


\subsubsection{Access Rights}

Access rights discuss the access to the resources through social values and norms and legal compliance. Access rights possess important position as the value co-creating interactions of systems are tools for changing system's accessing rights to the resources. These also have constraint on interactions and outcomes of service system. Spohrer \& Kwan (2009) described 4 types of access rights that are shared access (SA) owned outright (OO), privileged access (PA), and leased-contracted (LC).

Owned outright are associated with ownership and purchasing something and all responsibilities and rights are accompanying with this possession. Leased contracted arises with the rental or leased possession of something with certain and restricted rights. Shared access is associated with the shared usages of resources such as public roads, parks and information available on internet. Privileged access is concerned with absolute rights like personal background, private thoughts and relationships (Vargo, Lusch, \& Akaka, 2010). Overall understanding and considering of access rights are important and challenging in service system perspective as it may influence service design.

\subsubsection{Entities}

Service system entities are resource integrators that integrate their resources (operant and operand) for reciprocal exchange for co-creating value. Examples of service system entities are individuals, business organizations, government institutes and non-profit organizations etc. Katzan (2009) identified five types of entities which contribute to outcome with their specific role: service principal, service provider, service producer, service client and service object.

Service system entities are dynamic value co-creation configurations of different types of resources. Their interaction might be formal or informal. Informal interaction is based on promises and commitments (which may be explicit or implicit) and value, culture and social norms are involved in informal interactions. Formal interactions are involved with legal contract within the boundaries of a legal system and rights established by authorities or legal service entities (Vargo, Lusch, \& Akaka 2010a).

\subsubsection{Service System Interactions}

Two types of interactions (as depicted in Figure 1) exist during resource integration among service system's (Spohrer \& Kwan, 2009).

Value co-creating interactions are also known as value proposition based interaction mechanisms. These interactions are based on promise or contract agreed by service entities with believe to co-create value. Value can be proposed in the form of informal promises, business contracts and trade agreements (Spohrer, Anderson, Pass, \& Ager 2008).

Governance interactions occur to ensure the viability and efficiency of service system and to certify the compliance of policies and regulations. If value is not realized or created as was expected while offering the value proposal then 
it may create some dispute between service system s entities (Spohrer \& Kwan 2009; Adams 2000; Omerod 2005; March 1988).

\subsubsection{Outcome}

Service systementities integrate their resources through service interactions and co-create value as outcome of service interactions. Spohrer et al. (2008) proposed their Interact-Service-Propose-Agree-Realize (ISPAR) model to better understand the service system outcome.

ISPAR model presents outcome of service system interaction at 10 different levels which are 1) at first level value is realized and at $2^{\text {nd }}$ level 2) the proposal for value is not understood. 3) If the proposal is rejected to another service system, 4) and value is non-realized then there will arise no disputes. 5) If value co-creation dispute is created then there are two choices, it is resolved and solution is accepted by all stakeholders, 6) or disputes resolution are not accepted by all stakeholder. 7) Then interaction among service system will be non-service interaction and accepted. 8) In the case of unaccepted non-service interaction may lead to non-criminal activities 9) or unaccepted non service interaction may lead to criminal which result is justice 10) or unaccepted non service interaction may lead to criminal which result is non-justice (as shown in Figure 2). ISPAR model present more realistic picture of outcome rather than game player outcome (win-win, lose-win, win-lose, lose-lose).

\subsubsection{Measures}

Standardized measures are essential for the accountability and credibility of service system. Measures are categorized into four primary types: productivity,

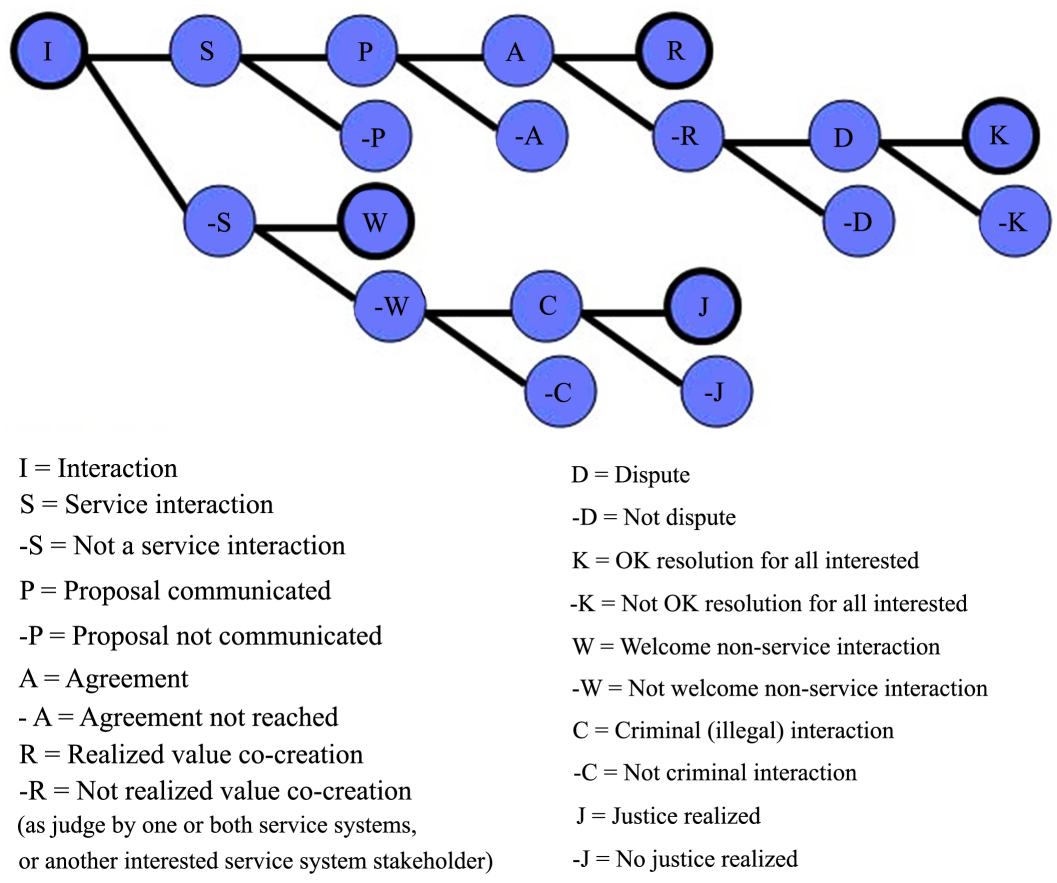

Figure 2. ISPAR model of service interactions. Source: Maglio et al. (2009). 
quality, sustainable innovation and compliance (as depicted in Figure 1). These measures are relevant to four dominant stakeholders' perspectives: customer, providers, authorities and competitors. Customers assess and evaluate the quality, providers determine the level of productivity, competitors appraise sustainable innovation and authorities are responsible to assess compliance (Spohrer \& Kwan, 2009).

\subsubsection{Stakeholders}

Stakeholders are categorized into four types: authority, customers, providers and competitors who have access to resources. These stakeholders design value co-creation mechanism and governance mechanism (Barile \& Polese, 2010).

\subsubsection{Network}

Service systems interact with each other for the purpose of reciprocal service exchange through value proposition. Pattern of interaction can be viewed as network. Routine interactions are based on relationships. In a service system network, these relationships are responsible to satisfy multiple stakeholders by value creation (Christopher, Payne, \& Ballantyne, 2002). To evaluate the networks of a service system it can be viewed at four levels: internal network, external network, virtual network and physical network.

\subsubsection{Ecology}

As in bio ecosystem, all living organism interact and influence in nature. In service system ecology, all service system entities interact and influence other service systems (Barile \& Polese, 2010).

\section{Method}

Research method is an enquiry strategy, based on the underlying assumptions moves to research design, data collection and data analysis (Myers, 2013; Creswell, 2013). By keeping the objective of this study in mind, researchers considered relativist ontology and subjective epistemology. This study employed the interpretivist assumptions with qualitative research techniques. Data was collected through 5 in-depth interviews to gain insights into the phenomenon of Akuwat microfinance system. Interviews were conducted from the employees of Akhuwat microfinance, who were most resourceful. The respondents belonged to the executive and managerial category from HR, Marketing and Project Management department. Each interview lasted approx. 75 minutes. Collected data was then analyzed by using traditional text coding and category generation method. Efforts were made to develop themes of similar concepts and categories, so the service system framework can be described.

\section{Case Study: Akhuwat Foundation Microfinance Project}

\subsection{Case Description}

Akhuwat Foundation was formed in 2001 in Lahore, the city of Pakistan with the 
aim to provide interest free loans to under privileged member of the society. The goal is to reduce poverty and elevate the economic situation. Following the ideology of Islamic microfinance "Qarz e hasna", Akhuwat started with minimal financial resources. Within 2 years of its operation, the financial resources increased as well as the recovery rate reached 100\% (Kaleem \& Ahmed, 2009).

Akhuwat is guided by four guiding rules: 1) interest free loan, 2) Linkages with Religious Places to raise and disperse loan, 3) Spirit of volunteerism and 4) Transforming borrowers into donors Akhter, Akhtar, \& Jaffri 2009). Akhuwat microfinance project is providing different types of loans to its borrowers as per their need and evaluation like family enterprise loan, housing loan, education loan, marriage loan, liberation loan, health loan and emergency loan. Staff assesses and evaluates need and reliability of borrower through field visits, feedback of community and credibility of guarantees (Kaleem \& Ahmed, 2009).

\subsection{Analysis \& Discussion}

Data analysis provided an in-depth description of Akhuwat Microfinance service system. Table 2 outlines each of the components of Akhuwat microfinance service system. Following is detailed description of each component.

\subsubsection{Resources}

While evaluating Akhuwat microfinance project as a service system, we identified two types of resources (operant and operand) and further subdivided them into four types: physical with rights, non-physical with rights, physical with no rights and non-physical with no rights (as depicted in Table 2).

Akhuwat has strong collaboration with other organizations, donor agencies, replicators and supporters which are categorized as operant resources with rights. Organization website and social media groups also fall in the category of operant resources but without rights. While evaluating operand resources, we found staff, administration, volunteers, borrowers, and individual donors with rights and furniture, computers, transports, building, MIS system, phones without rights.

\subsubsection{Access Rights}

In Akhuwat service system building, transport, furniture, computers and MIS system etc. are owned outright of service system. Akhuwat has no resources at lease. It has the ownership of all of its resources. Website, social media, e-books and other published materials have shared access and relation with borrowers and donor, affiliation with replicator organization and innovative ideas of organization are privileged rights.

\subsubsection{Entities}

Executive director and board of directors are service principal as they are the legal and authorized owners of this service system. Donor, supporters and administration are service producers as they provide back end support and production for service offering. Microfinance department, IT department, finance department 
Table 2. Akhuwat microfinance service system.

\begin{tabular}{|c|c|}
\hline Concepts & Akhuwat Microfinance Service System \\
\hline \multirow{4}{*}{ Access Rights } & Owned Outright. Building, motor bikes, computers, furniture, MIS system \\
\hline & Leased/Contracted: nothing is at lease \\
\hline & Shared Access: Implementing partner of CM self-employment scheme \& CM interest free loan scheme \\
\hline & $\begin{array}{l}\text { Privileged Access: Relationship with borrowers, donors and community and good will, affiliation with replicator } \\
\text { organizations, innovative ideas }\end{array}$ \\
\hline \multirow{10}{*}{ Resources } & Operant (Conceptual) \\
\hline & With rights (Organizations): Associations, replicator organizations. Donors, supporters \\
\hline & Without rights (Shared information): Website, social media, (twitter \& Facebook), \\
\hline & Language: English, Urdu, local languages \\
\hline & $\begin{array}{l}\text { Laws: Registration under Societies Registration Act of 1860, Registration, with Pakistan Centre for Philanthropy } \\
\text { (PCP), member of Pakistan Microfinance Network (PMN). }\end{array}$ \\
\hline & Methods: Field visit, monitoring \& evaluation, internal audit, \\
\hline & Measures: Borrowers feedback, empowerment, loan recovery, audit report, financial report \\
\hline & Operand (Physical) \\
\hline & With rights (people): Staff, administration, volunteers, borrowers, individual donors \\
\hline & Without rights (Technology): Furniture, computers, transports, building, MIS system, phones \\
\hline \multirow{5}{*}{ Entities } & Service Principal: Executive director (Dr. Amjad Saqib) \& board of directors \\
\hline & $\begin{array}{l}\text { Service Producer. Donor, borrowers (when becomes donor), administration, and loan department, finance department, } \\
\text { IT department, banks }\end{array}$ \\
\hline & Service Provider. Staff, loan officers, information desk and volunteers \\
\hline & $\begin{array}{l}\text { Service Clients/Service Customers : Borrowers, entrepreneurs, poor community, students, poor families, } \\
\text { debtor and poor patients, }\end{array}$ \\
\hline & $\begin{array}{l}\text { Service Object. Interest free loans (family loan, housing loan, health loan, liberation loan, marriage loan, } \\
\text { education loan, emergency loan) }\end{array}$ \\
\hline \multirow{4}{*}{ Stakeholders } & Customer. Borrowers (Students, poor community, families, enterprisers, debtor and poor patients). \\
\hline & Provider. Donors, supporters, associations, administration, IT department, finance department, loan dept \\
\hline & Authority: Executive director, board of directors, administration \\
\hline & Competitors: Akhuwat has no competitor and believe on replication \\
\hline \multirow{4}{*}{ Interaction } & Governance interactions: Interaction with government, FBR, legitimate institutions \\
\hline & Value Co-creation: Interaction with borrowers, banks, community, religious places, staff and other stakeholders \\
\hline & $\begin{array}{l}\text { Value Proposition: Initial dialogues, community meeting, development of business plan, fund raising campaigns, } \\
\text { project presentations }\end{array}$ \\
\hline & Value Elements: empowerment, long term relationship, satisfaction \\
\hline
\end{tabular}

Internal: Staff, HR department, IT department, finance department, administration, loan department

External: Borrowers, donors, replicator organizations, associations, supports, government agencies

Networks

Virtual: Website, Blog, Face book, Twitter, e-books,

Physical: Training centers, religious places

Value realized: acceptance of idea, conversation, meetings, business plans, recovery, empowerment

Borrower's Outcome: empowerment, financial stability,

Outcome

Akhuwat Outcome: community empowerment, recovery,

Donor Outcome: fair utilization, empowerment, transparency 
Quality: (Evaluated by borrowers) Level of satisfaction, loan processing time period, assistance and guidance on business plan, easy recovery, fulfillment of need on time

Measure

Productivity: (Evaluated by providers) accountability, audit report, financial report, satisfaction of donor

Compliance: (Evaluated by authorities) policies and regulation, tax provision, relation with legitimate institutes

Sustainable innovation: (Evaluated by competitors) Akhuwat microfinance has no competitor and support other organization in replication of its model

and staff apply their competences and skills for borrowers (customers) while playing the role of service provider. Borrowers (community, students, poor, patients) are service customers and different service offerings by Akhuwat service system (different types of interest free loan) are the service object.

\subsubsection{Service System Interactions}

In service system interactions, value co-creation is occurred through the interaction and collaborations of borrowers, community, staff and other stakeholders. Initial dialogues, community meeting, interest free loan offer, development of business plan are the elements of value proposal in perspective of borrower but value is proposed to donor with presentation of work, success stories and fund raising campaigns. Empowerment, long term relationship, satisfaction are value elements in the process of co-creating value. To handle disputes and occurrence of value proposal rejection and situation of not realized value, governance interactions occur with government, FBR and other legitimate institutions (as depicted in Table 2).

\subsubsection{Outcome}

Community empowerment and poverty alleviation is the outcome in Akhuwat microfinance service system. Clients comes with their ideas, business plans, competences and aim to empower themselves financially by securing interest free loan. Staff of Akhuwat plays an important role to guide, support and motivate clients to co-create financial empowerment.

\subsubsection{Stakeholders}

According to service system framework, stakeholders are categorized into customers, providers, authorities and competitors. Akhuwat's borrowers who apply for interest free loans are customers and donors, supporters, associations, administration, staff and loan department, play the role of providers. Executive director and board of directors are the authority stakeholders. Akhuwat is the only interest free microfinance service system exists in the Pakistan and claimed to be in the whole world as well so it doesn't have any competitor and also believe on the concept of replication. Akhuwat support and encourage others to replicate its interest free microfinance model to reduce poverty from the world. 


\subsubsection{Measures}

Measures are viewed from the perspective of shared information and governance mechanism. In service system measure are evaluated in terms of productivity, quality, sustainable innovation and compliance. In Akhuwat service system quality is evaluated by customer's level of satisfaction, loan processing time period, assistance and guidance on business plan, easy recovery and fulfillment of need on time. Providers evaluate productivity by monitoring, accountability, audit report, financial report and satisfaction of donors. Authorities determine the compliance issues by following policies and regulations, getting tax provision and try to stable its relation with legitimate institutions.

\subsubsection{Network}

Akhuwat is establishing its networks at four different levels. Internal networks are concerned with staff, HR department, IT department, finance department, administration, and loan department. External network covers borrowers, donors, replicator organizations, associations, supports and government agencies. To connect people virtually, they use website, blog, Facebook, twitter, and eBooks. For physical networking it gather people on religious places to disburse loans and arrange training programs to enhance the capabilities of resources.

\subsubsection{Ecology}

Akhuwat microfinance is working with the mission to reduce poverty from $\mathrm{Pa}$ kistan. It is growing on a rapid pace. Akhuwat has 396 branches all over Pakistan with 7 million beneficiaries and has disbursed 21 billion rupees loans with 99.9\% recovery rate. They are also encouraging other entities in the ecology to replicate their service model.

\section{Conclusion}

By applying the service system framework and interview guide developed by Lyon and Tracy (2013), we evaluated Akhuwat microfinance service system. S-D logic view concentrates on the benefits and betterment of actors. We find that Akhuwat service system is classified as customer centric, and follows the spirit of S-D logic conceptualization of business.

Akhuwat Microfinance service system interacts with other service systems and integrates its resources to co-create mutually beneficial value by involving all actors in entire process. Value co-creating interactions occur at two levels: interaction with donor agencies and interaction with borrowers. At donor level, value is proposed in the shape of promise to the cause. If value is realized, then it is evaluated through different tools adopted by donor like accountability, third party evaluation, audit report, financial report and level of satisfaction. In the case of value failure, there might be some conflicts and disputes and governance interactions come into place to settle these disputes.

At a borrower level, value is proposed in the form of interest free loan and financial empowerment through dialogues, meetings and business plans. Both 
systems integrate their resources as Akhuwat presents its financial and human resources, assistance and guidance and borrowers come with the spirit to change their lives with their physical and mental resources. Value is realized in the form of borrower's economic empowerment, relationship between both service systems and promised output. Further value is evaluated by borrower's level of satisfaction, loan processing time period, assistance and guidance on business plan, easy installments and fulfillment of need on time. If value is not realized then it may appear in the form of overdue, loss in business, dissatisfaction and disputes.

There is a dire need of empirical studies in the service systems literature. Future researchers should look at other sectors, as well as organizations and apply the same framework to outline the service system of the targeted organization. Since Akhuwat Foundation is interested in disbursing the knowledge and sharing the cause, service system illustration presented in this paper will also help others in the community to follow the path of social welfare success. Akhuwat microfinance service system representation is also beneficial for those community members, who are interested in replicating and sharing the cause of Akhuwat foundation.

\section{Conflicts of Interest}

The authors declare no conflicts of interest regarding the publication of this paper.

\section{References}

Adams, J. (1995/2000). Risk. London: Routledge.

Akhter, W., Akhtar, N., \& Jaffri, S. K. A. (2009). Islamic Micro-Finance and Poverty Alleviation: A Case of Pakistan. In Proceeding of the 2nd CBRC (pp. 1-8). Lahore.

Barile, S., \& Polese, F. (2010). Smart Service Systems and Viable Service Systems: Applying Systems Theory to Service Science. Service Science, 2, 21-40. https://doi.org/10.1287/serv.2.1 2.21

Brodie, R. J., Saren, M., \& Pels, J. (2011). Theorizing about the Service Dominant Logic: The Bridging Role of Middle Range Theory. Marketing Theory, 11, 75-91. https://doi.org/10.1177/1470593110393714

Bryson, J. R., Daniels, P. W., \& Warf, B. (2004). Service Worlds: People, Organisations, Technology. New York and London: Routledge.

Christopher, M., Payne, A., \& Ballantyne, D. (2002). Relationship Marketing: Creating Shareholder Value. New York: Routledge.

Creswell, J. W. (2013). Research Design: Qualitative, Quantitative, and Mixed Methods Approaches. New York: Sage Publications.

Kaleem, A., \& Ahmed, S. (2009). The Quran and Poverty Alleviation: A Theoretical Model for Charity-Based Islamic Microfinance Institutions. Nonprofit and Voluntary Sector Quarterly, 39, 409-428. https://doi.org/10.1177/0899764009332466

Katzan Jr., H. (2009). Principles of Service Systems: An Ontological Approach. Journal of Service Science, 2, 35. https://doi.org/10.19030/jss.v2i2.4285 
Lusch, R. F., \& Vargo, S. L. (2014). The Service-Dominant Logic of Marketing: Dialog, Debate, and Directions. New York: Routledge.

Lusch, R. F., Vargo, S. L., \& Wessels, G. (2008). Toward a Conceptual Foundation for Service Science: Contributions from Service-Dominant Logic. IBM Systems Journal, 47, 5-14. https://doi.org/10.1147/sj.471.0005

Lyons, K., \& Tracy, S. (2013). Characterizing Organizations as Service Systems. Human Factors and Ergonomics in Manufacturing \& Service Industries, 23, 19-27. https://doi.org/10.1002/hfm.20517

Maglio, P. P., \& Spohrer, J. (2008). Fundamentals of Service Science. Journal of the Academy of Marketing Science, 36, 18-20. https://doi.org/10.1007/s11747-007-0058-9

Maglio, P. P., Kieliszewski, C. A., Spohrer, J. C., Lyons, K., Patrício, L., \& Sawatani, Y. (2019). Handbook of Service Science, Volume II. Berlin: Springer International Publishing. https://doi.org/10.1007/978-3-319-98512-1

Maglio, P. P., Vargo, S. L., Caswell, N., \& Spohrer, J. (2009). The Service System Is the Basic Abstraction of Service Science. Information Systems and e-Business Management, 7, 395-406. https://doi.org/10.1007/s10257-008-0105-1

Maglio, P., Bailey, J., \& Gruhl, D. (2007). Steps toward a Science of Service Systems. Computer, 40, 71-77. https://doi.org/10.1109/MC.2007.33

March, J. G. (1988). Introduction: A Chronicle of Speculations about Decision-Making in Organizations. In J. G. March (Ed.), Decisions and Organizations (pp. 1-21). Oxford: Blackwell.

March, J. G. (1991). Exploration and Exploitation in Organizational Learning. Organization Science, 2, 71-87. https://doi.org/10.1287/orsc.2.1.71

Myers, M. D. (2013). Qualitative Research in Business and Management. New York: Sage Publications.

Normann, R. (2001). Reframing Business: When the Map Changes the Landscape. Hoboken, NJ: John Wiley \& Sons.

Omerod, P. (2005). Why Most Things Fail: Evolution, Extinction and Economics. New York: Pantheon Books.

Simon, H. A. (1996). The Sciences of the Artificial. Cambridge, MA: MIT Press.

Spohrer, J., \& Kwan, S. K. (2009). Service Science, Management, Engineering, and Design (SSMED): An Emerging Discipline-Outline and References. International Journal of Information Systems in the Service Sector, 1, 1-31. https://doi.org/10.4018/jisss.2009070101

Spohrer, J., \& Maglio, P. P. (2010). Service Science: Toward a Smarter Planet. In W. Karwowski, \& G. Salvendy (Eds.), Introduction to Service Engineering (pp. 3-30). New York: Wiley \& Sons.

Spohrer, J., Anderson, L., Pass, N., \& Ager, T. (2008). Service Science and Service-Dominant Logic.

Vargo, S. L. (2011). Market Systems, Stakeholders and Value Propositions: Toward a Service-Dominant Logic-Based Theory of the Market. European Journal of Marketing, 45, 217-222. https://doi.org/10.1108/03090561111095667

Vargo, S. L., \& Lusch, R. F. (2004). Evolving to a New Dominant Logic for Marketing. Journal of Marketing, 68, 1-17. https://doi.org/10.1509/jmkg.68.1.1.24036

Vargo, S. L., \& Lusch, R. F. (2016). Institutions and Axioms: An Extension and Update of Service-Dominant Logic. Journal of the Academy of Marketing Science, 44, 5-23. https://doi.org/10.1007/s11747-015-0456-3 
Vargo, S. L., \& Lusch, R. F. (2018). The SAGE Handbook of Service-Dominant Logic. New York: SAGE Publications Limited. https://doi.org/10.4135/9781526470355

Vargo, S. L., Lusch, R. F., \& Akaka, M. A. (2010a). Advancing Service Science with Service-Dominant Logic. In Handbook of Service Science (pp. 133-156). Boston, MA: Springer US. https://doi.org/10.1007/978-1-4419-1628-0 8

Vargo, S. L., Lusch, R. F., Akaka, M. A., \& He, Y. (2010b). The Service-Dominant Logic of Marketing: A Review and Assessment. Review of Marketing Research, 6, 125-167. https://doi.org/10.1108/S1548-6435(2009)0000006010

Vargo, S. L., Lusch, R. F., Akaka, M. A., \& He, Y. (2020). Service-Dominant Logic. In The Routledge Handbook of Service Research Insights and Ideas (p. 3). Abingdon-on-Thames: Routledge. https://doi.org/10.4324/9781351245234-1

Williams, J., \& Aitken, R. (2011). The Service-Dominant Logic of Marketing and Marketing Ethics. Journal of Business Ethics, 102, 439-454. https://doi.org/10.1007/s10551-011-0823-Z

Winklhofer, H., Palmer, R. A., \& Brodie, R. J. (2007). Researching the Service Dominant Logic-Normative Perspective versus Practice. Australasian Marketing Journal (AMJ), 15, 76-83. https://doi.org/10.1016/S1441-3582(07)70033-2 